\title{
Sports and Recreational Activities of the Disabled From Eastern Regions of Poland
}

Authors' contribution:

A) conception and design of the study

B) acquisition of data

C) analysis and interpretation of data

D) manuscript preparation

E) obtaining funding

\section{Barbara Bergier ${ }^{\text {A-D }}$, Zofia Kubińska ${ }^{\text {AC }}$, Józef Bergier ${ }^{\text {ACE }}$}

Pope John Paul II State School of Higher Education in Biata Podlaska, Poland

\section{ABSTRACT}

The primary objective of the study was recognition of the forms of sports and recreational activities of the disabled living in the regions of Rzeszów, Lublin and Białystok, and determination of the benefits drawn by them from participation in these activities. A total number of 750 were examined. The representative group was selected by the stratified random sampling method. The study was conducted by the method of a diagnostic survey. Research material was collected by means of mutually supplementary research techniques: questionnaire, interview, observation, and analysis of documentation.

A detailed analysis of the results obtained allowed the presumption that more than half of the people with disabilities from the eastern regions of Poland participate in sports-recreational activities, with the largest number of respondents with a mild degree of disability.

The majority of respondents approach their participation in sports-recreational activities not simply as a form of therapeutic rehabilitation. Respondents most frequently participated in walks, marches, and rehabilitation gymnastics. The largest percentage of respondents had never participated in hydrobics, horseback riding, hippotherapy, and swimming.

A considerable number of the respondents would like to participate in - apart from walks, marches, and rehabilitation gymnastics - team games and swimming. According to the respondents' opinions, forms of sports-recreational activities that are most recommended with respect to the degree and type of disability are: rehabilitation gymnastics, walks, marches, and swimming.

Due to the participation in sports-recreational and tourism activities, those with disabilities have a good general well being, their state of health improves, they make new acquaintances and social contacts, make new friends, and elevate their physical efficacy and endurance. The respondents also indicated a change from sedentary lifestyle as well as satisfaction from overcoming both imperfections of own body and anxiety resulting from disability. 


\section{Introduction}

"Physical activity as a medicine has neither substance nor wrapping. The substance of this drug is the idea born from science and experience. Its administration requires genuine mastery. Passing this activity (...) together with personality and heart makes this drug irreplaceable” (Prof. W. Dega).

According to the Convention on the Rights of Persons with Disabilities adopted on 13 December 2006 in New York and ratified by Poland on 6 September 2012, "persons with disabilities include those who have long-term physical, mental, intellectual or sensory impairments which, in interaction with various barriers, may hinder their full and effective participation in society on an equal basis with others" (United Nations ..., 2006; The Convention ..., 2006).

"The purpose of the present Convention is to promote, protect and ensure the full and equal enjoyment of all human rights and fundamental freedoms by all persons with disabilities, and to promote respect for their inherent dignity".

In Article 30 concerning the participation of the disabled in cultural life, recreation, leisure and sports it is stated: 'With a view to enabling persons with disabilities to participate on an equal basis with others in recreational, leisure and sporting activities, States Parties shall take appropriate measures:

a) to encourage and promote the participation, to the fullest extent possible, of persons with disabilities in mainstream sporting activities at all levels,

b) to ensure that persons with disabilities have an opportunity to organize, develop and participate in disability-specific sporting and recreational activities and, to this end, encourage the provision, on an equal basis with others, of appropriate instruction, training and resources,

c) to ensure that persons with disabilities have access to sporting, recreational and tourism venues,

d) to ensure that children with disabilities have equal access with other children to participation in play, recreation and leisure and sporting activities, including those activities in the school system,

e) to ensure that persons with disabilities have access to services from those involved in the organization of recreational, tourism, leisure and sporting activities" (The Convention ..., 2006).

The nearest future will show within what scope and how fast it will be possible to implement into practice the above-mentioned guidelines. It is an obvious fact that the participation of the disabled in physical activity is much more difficult (Smith, 1987, pp. 376-89; Murray and Sproats, 1990, pp. 9-14; Spinhoven et al., 2004, pp. 211-19). The participation of the disabled in these types of activities requires considerable caution, because the risk of falls and fractures is higher (Suzukowa et al., 2009, pp. 334-40). For example, patients with degenerative joint disease encounter great difficulties already in the case of longer walking (Solignac, 2004, pp. 19-20). The adjustment of physical activity into the type and degree of disability is a very important issue, therefore, a special preparation of medical staff for this purpose is recommended (Bergier, 2010, pp. 1134-40; Murphy and Carbone, 2008, pp. 1057-61). It should also be remembered that still there exist architectural barriers which, to a great extent hinder the participation of these people in physical activity, hence, assistance from the State seems to be indispensable (Riley et al., 2008, 158-68; Freeman and Selmi, 2010, pp. 471-85; Burns et al., 2009, pp. 403-17).

In literature in recent years, increasingly more often the scope of problems has been undertaken concerning the participation of the disabled in motor activities, including reports indicating an important place of physical activity of the disabled during leisure time, the amount of which they possess being considerably larger (Solignac, 2004, pp. 19-20; Freeman and Selmi, 2010, pp. 471-85; Bekesi et al., 2011, pp. 9-43; Buzinde and Yarnal, 2012, pp. 783-87; Kubińska et al., 2011, pp. 189-193; Robinson et al., 2004, pp. 179-93; Cocchiarella et al., 2001, pp. 129-39). The social role of participation in these types of activities which creates opportunities for integration is also important (Wilken, 1997, pp. 121-5).

Motor activity among the disabled also concerns their participation in sports competitions, aimed at using sports in the rehabilitation process, and the concept of 'therapeutic recreation' becomes increasingly popular and needed for the development of specified actions to identify the disabled persons who may 
participate in an individual sport, even on an elite/exclusive level (Chockalingam et al., 2012, pp. 270-7). Paralympic sports events play a great and very important role, which create an opportunity to present the skills and capabilities of the disabled, and also serve as a 'catalyst' for the rights of this population group through the provision of integration, equality of chances and an access to the architectonic environment. The role of the media reporting Paralympics should also be emphasized, which have led to an increase in the awareness of the possibility for the disabled to participate in sports and, at the same time, to show physical activity as health prophylaxis. The power of sports in enormous. Due to the participation in sports the disabled promote their health, their rights, they integrate socially, there increases their sense of own effectiveness and self-esteem, and their quality of life becomes better (Blauwet amd Willick, 2012, pp. 851$6)$.

For the disabled, sports and recreation are important elements of rehabilitation - they increase the body efficacy and endurance, and improve psychological status (Zdebski and Gordon, 2005, pp. 11-14). Due to the recreational and sports activity of the disabled, apart from experiencing pleasure and joy, they are mentally stimulated, train reflexes, self-disciple, become self-confident, cooperate and compete with others; thus they join social life (Barlak and Włostowska, 2006, pp. 222 -227).

The results of representative studies confirm that disability is the phenomenon which in Poland shows an alarming growing tendency. During the last 25 years, the number of the disabled increased by more than twice (from 2.5 million in 1978 - 5.5 in 2002) (Sikorska, 2005), Barlak and Włostowska were right to state that this tendency should also be accompanied by an equally intensive search for solutions in the area of creating an equal opportunities society (Barlak and Włostowska, 2006, pp. 222-227). (...) In this situation, the actions by the State, as well as those by non-government institutions, become especially important in the creation of conditions in which both the disabled and people not afflicted by any form of physical or mental disability could participate in the social, economic and cultural life of the country with equal rights and equal opportunities. Perhaps in the nearest years we will know the effects of the implementation into life of the Convention on the Rights of Persons with Disabilities.

\section{Objective and research problems}

The objective of the study was recognition of the forms of sports-recreational activities, as well as benefits drawn from participation in these activities by the disabled living in the regions of Rzeszów, Lublin, and Białystok.

The following research problems were posed:

1. Participation of the disabled from the eastern regions of Poland in sports-recreational activities;

2. Participation in sports-recreational activities as a form of therapeutic rehabilitation;

3. Forms of sports-recreational activities in which the respondents most willingly participate or would like to participate, and which they consider as most recommended considering the degree and type of their disability;

4. Benefits drawn by the disabled from the participation in sports-recreational activities.

\section{Material and methods}

The study was conducted during the period from June - October 2006 in three regions: Rzeszów, Lublin, and Białystok, and covered a total number of 750 disabled. The representative group was selected by the method of stratified random sampling. The respondents were selected by trained surveyors.

The study was carried out by the method of a diagnostic survey, and the research material was collected using mutually supplementary research techniques: questionnaire, interview, observation, and analysis of records. Statistically significant differences were calculated using chi-square test. 


\section{Results}

The results of the study show various aspects of the participation of the disabled from the eastern regions of Poland in sports-recreational activities, and the benefits from participation in these activities perceived by the respondents. The data obtained were illustrated in figures, with detailed description and information concerning statistically significant differences.

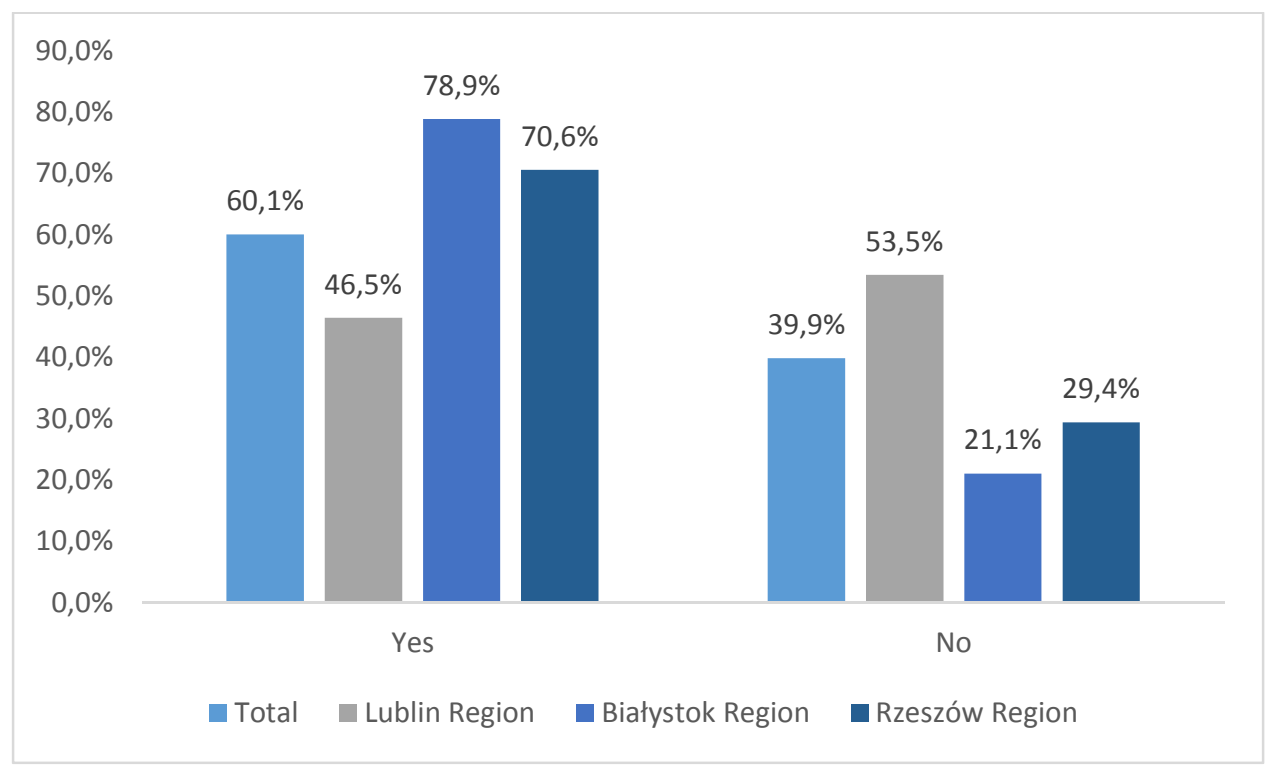

Figure 1. Participation of the disabled in sports-recreational activities Source: own study.

The fact that $60.1 \%$ of the disabled declared participation in sports-recreational activities instils optimism. However, a great variation of results was observed according to individual regions. In the Białystok Region, the percentage of those respondents was the highest $-78.9 \%$, followed by the Rzeszów Region $-70.6 \%$, while more than a half of respondents (53.5\%) from the Lublin Region unfortunately did not participate in any sports-recreational activities (Fig. 1).

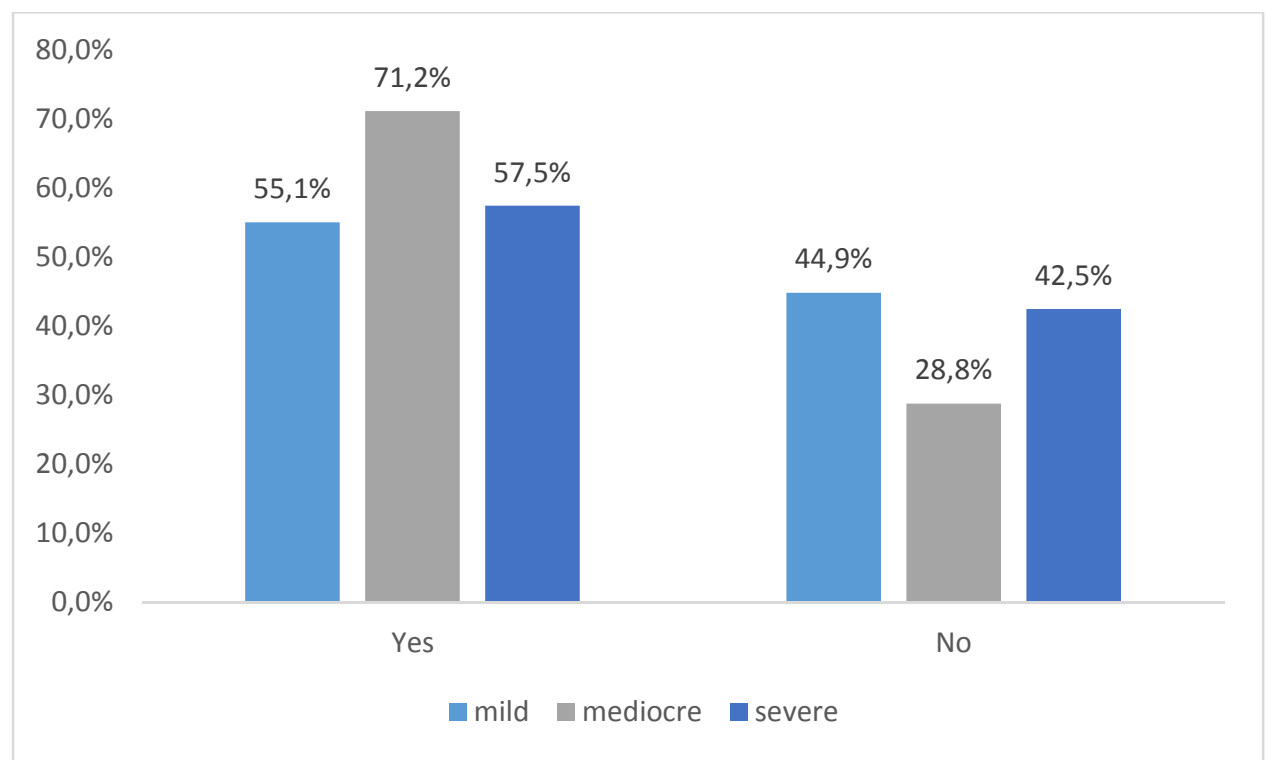

Figure 2. Respondents'participation in sports-recreational activities with consideration of the degree of disability. Source: own study. 
The largest group of respondents (71.2\%) participating in sports-recreational activities were those with a moderate degree of disability. The percentage of the disabled participating in these activities in the remaining groups was similar: low level of disability $-55.1 \%$, severe level of disability $-57.5 \%$ (Fig. 2).

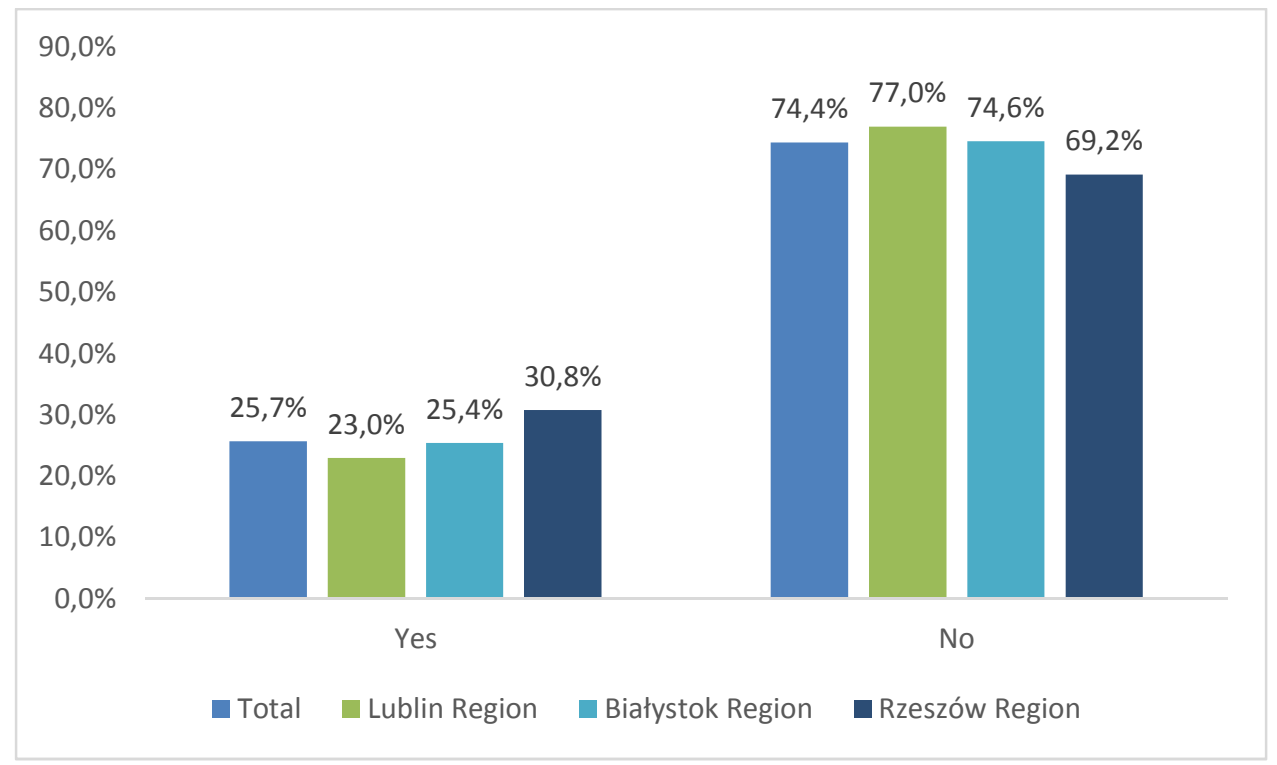

Figure 3. Participation in sports-recreational activities approached by respondents exclusively as a form of therapeutic rehabilitation.

Source: own study.

The majority of respondents (74.3\%) consider recreational activities not only as a form of therapeutic rehabilitation. The data from three regions are similar. Every fourth respondent on average expressed an opposite opinion (considered recreational activities exclusively as a form of therapeutic rehabilitation).

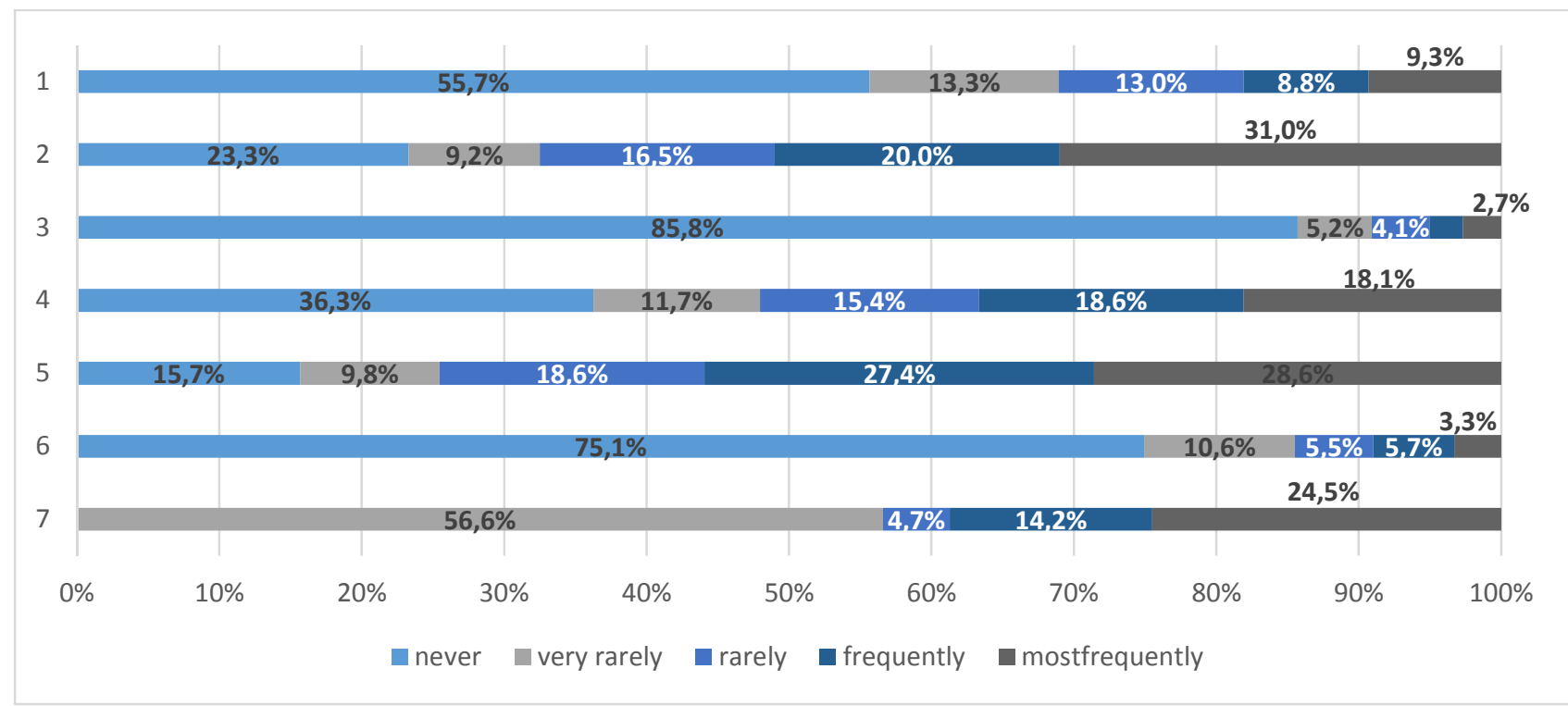

1. Swimming; 2. Rehabilitation gymnastics; 3. Hydrobics; 4. Team games; 5. Walks, marches; 6. Horseback riding, hyppotherapy; 7. Other.

Figure 4. Forms of sports-recreational activities in which the respondents most frequently participate Source: own study.

The respondents participated 'often' and 'most frequently' in walks and marches (56.0\%), as well as in rehabilitation gymnastics $(51.0 \%)$. The percentage values concerning team games were similar; $36.3 \%$ of 
respondents 'never' participated in these activities, while $36.7 \%$ participated 'frequently' and 'most frequently'.

As many as $85.8 \%$ of respondents 'never' participated in hydrobics $(81.0 \%$ of urban inhabitants and $89.2 \%$ from rural areas), in horseback riding, hyppotherapy $-75.1 \%$, and in swimming $-55.7 \%$.

Among other forms of activities, the respondents mentioned: riding bicycle, races, table tennis, lawn tennis, fishing, yachting and weight training. Also, they often reported sports occupations without indicating the discipline.

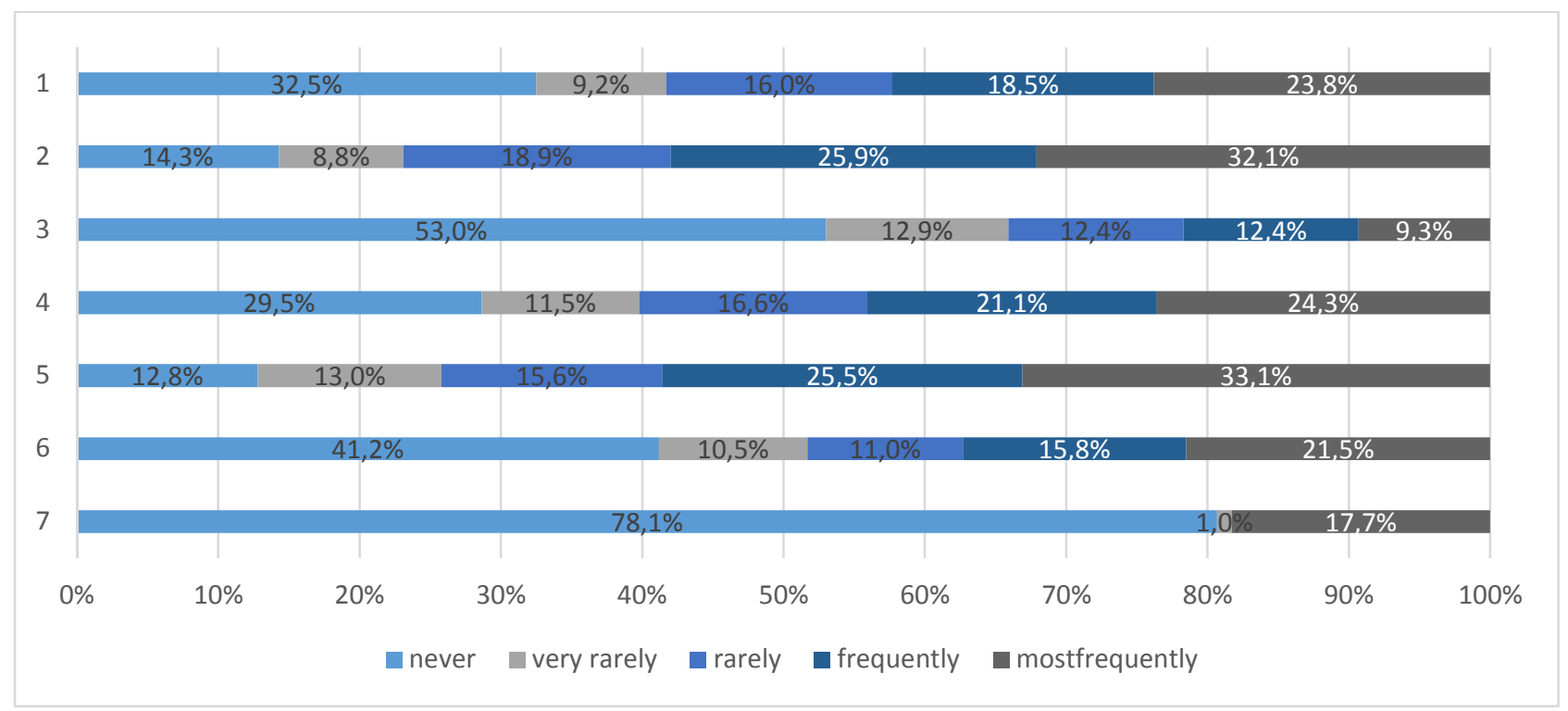

1. Swimming; 2. Rehabilitation gymnastics; 3. Hydrobics; 4. Team games; 5. Walks, marches; 6. Horseback riding, hyppotherapy; 7. Other.

Figure 5. Forms of sports-recreational activities in which the respondents would like to participate Source: own study.

After summing up the number of respondents who selected the options 'frequently' and 'most frequently', information was obtained that most frequently the respondents would like to participate in walks and marches (58.6\%), followed by rehabilitation gymnastics $(58.0 \%)$, team games (45.4\%), and swimming $(42.3 \%)$. All of these forms, except the last one, are commonly available, hence undoubtedly such choices. The category 'never' was selected by $53.0 \%$ of respondents who indicated hydrobics, $41.2 \%$ - horseback riding, hyppotherapy, and $32.5 \%$ - swimming. It seems that this is associated with the poor availability of the above-mentioned form of motor activities.

Within the categories 'others' the respondents additionally mentioned table tennis, riding bicycle, using water equipment, shooting, martial arts and dancing.

According to the respondents' opinions, the most recommended forms of sports-recreational activity were rehabilitation gymnastics $-68.1 \%$, followed by walks and marches $-56.7 \%$, and swimming $-44.4 \%$. The least recommended forms were hydrobics (48.2\%), horseback riding, hyppotherapy (45.5\%), sports games (37.2\%) and swimming (31.1).

The greatest benefit drawn by the disabled from tourism and sports-recreational activities are primarily good wellbeing (49.0\%), improvement of the state of health (44.7\%), making new acquaintances, social contacts, friends $(41.3 \%)$, elevation of efficacy and physical endurance $(37.2 \%)$, change of the sedentary style of life (34.1\%), and satisfaction from overcoming imperfections of own body and anxiety resulting from disability (25.3\%). Slightly fewer respondents indicated the performance of interests and aspirations (self-fulfilment $-19.9 \%$ ), and an opportunity to adjust to commonly adopted forms of spending leisure time (14.4\%). 


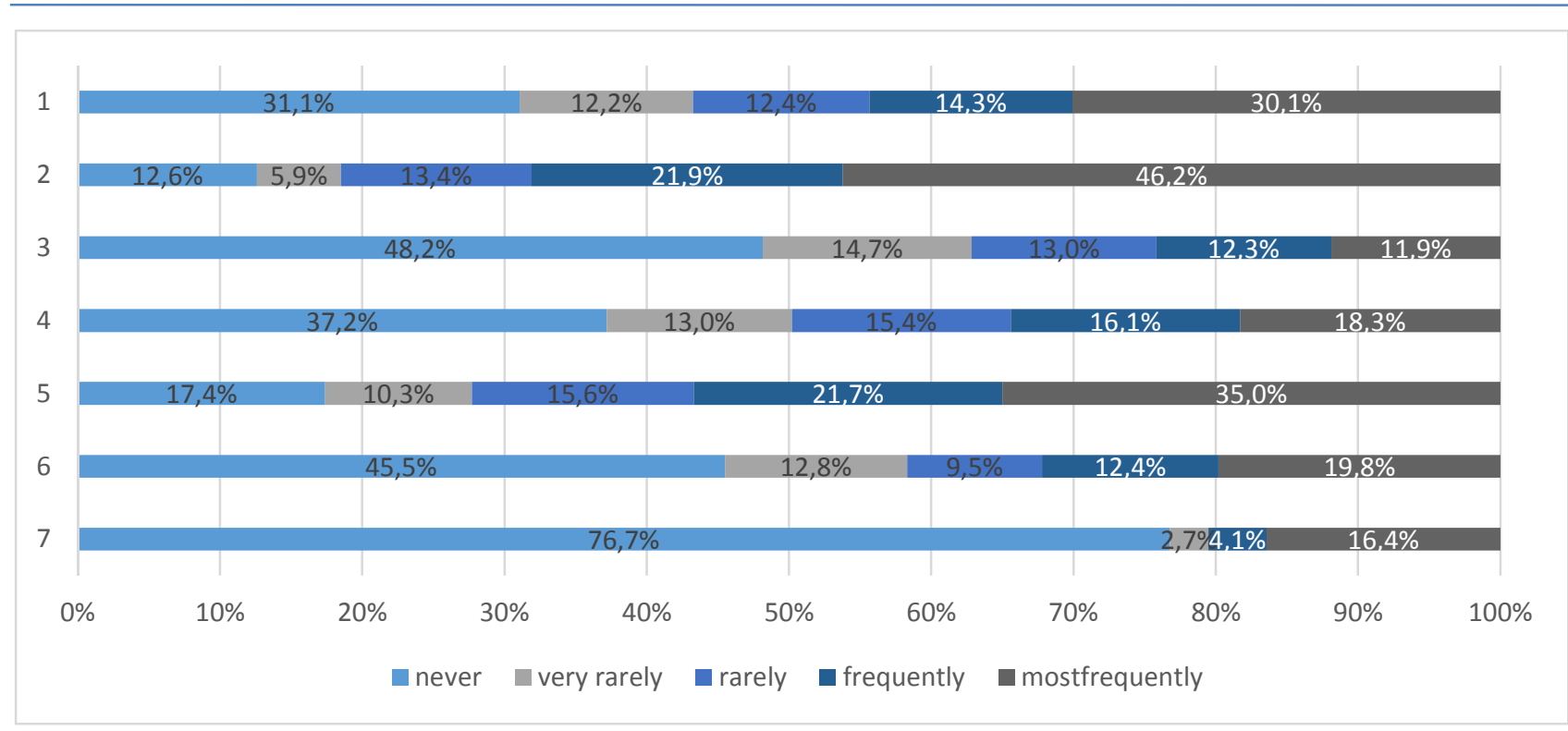

1. Swimming; 2. Rehabilitation gymnastics; 3. Hydrobics; 4. Team games; 5. Walks, marches; 6. Horseback riding, hyppotherapy; 7. Other.

Figure 6. Forms of sports-recreational activities considered by respondents as most recommended considering the degree and type of disability.

Source: own study.

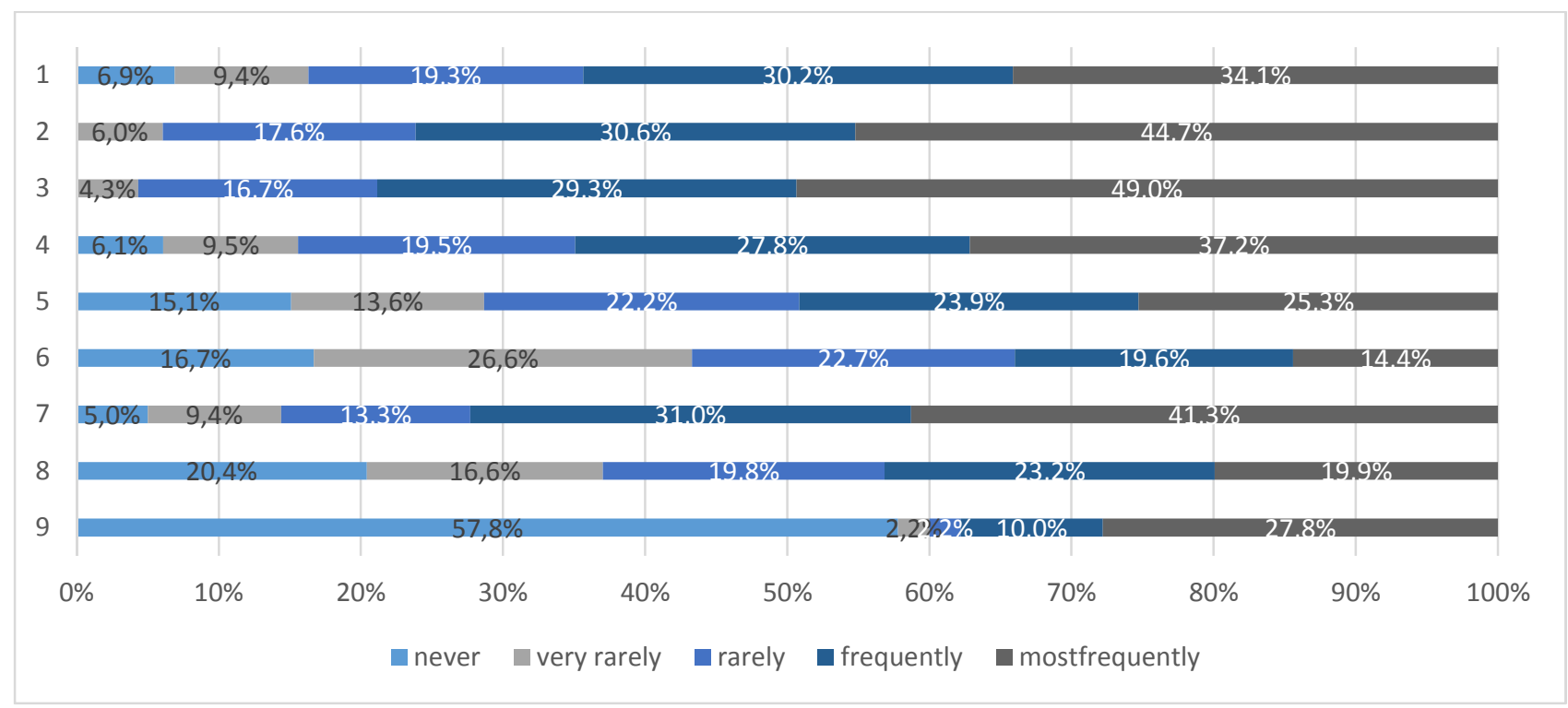

1. Change of sedentary style of life; 2. Improvement of state of health; 3. Good wellbeing; 4. Elevation of efficacy; 5. Satisfaction with overcoming; 6. Opportunities to adjust to; 7. Making new acquaintances, contacts; 8 . Realization of interests; 9 - Others

Figure 7. Benefits from participation in sports-recreational and tourism activities perceived by respondents.

Source: own study.

The least important benefits mentioned by the respondents were: fulfilment of interests and aspirations $-20.4 \%$, an opportunity to adjust to commonly adopted forms of spending leisure time $-16.7 \%$, and satisfaction from overcoming imperfections of own body and anxiety resulting from disability $-15.1 \%$.

Among indications within the category 'others', the disabled in the study reported: the possibility to go outside the home, improvement of psychological health, joy, satisfaction with the joy of significant others, observation of nature, overcoming own weaknesses, a way to spend an excessive amount of free time, and maintenance of body weight. 


\section{Summing up, conclusions and postulates}

The study showed that the majority of respondents participated in sports-recreational activities, and the largest group were those with a mediocre degree of disability. The majority of respondents approached participation in these activities not merely as a form of therapeutic rehabilitation but more comprehensively. From among the proposed forms of activities, more than a half of the disabled declared that they most frequently participated in walks, marches, and rehabilitation gymnastics and, to a considerably smaller extent, in team games. Among 'other' forms of activities the respondents most often mentioned bicycle riding and races. The majority of the disabled never participated in hydrobics, horseback riding, hyppotherapy and swimming.

The forms of physical activity in which the respondents would like to participate were very similar. Apart from walks, marches, rehabilitation gymnastics, and team games, a considerable number of respondents would like to participate in swimming. The disabled in the study reported the same forms of sports-recreational activity as most recommended with respect to the degree and type of disability; in this category the largest number of respondents indicated rehabilitation gymnastics.

Summing up, it may be presumed that according to the disabled the most attractive forms of sportsrecreational activity are those available for them (walks, marches and rehabilitation gymnastics, considerably less respondents indicated swimming). The respondents declared the same forms of sports-recreational activity as most recommended considering the degree and type of disability.

Among the benefits perceived by the respondents in participation in these activities they mentioned: good general wellbeing, improvement of the health status, making new acquaintances, social contacts and friends, elevation of the level of efficacy and endurance, change of sedentary life style, and satisfaction from overcoming imperfections of own body and anxiety resulting from disability.

A detailed analysis of the results obtained allowed the formulation of the following conclusions:

1. More than a half of the disabled from the eastern regions of Poland participate in sports-recreational activities, including the largest percentage from the Białystok Region (79\%), while the lowest percentage from the Lublin Region (46\%);

2. The largest number of respondents who participated in sports-recreational activities were those with a moderate degree of disability $(71 \%)$. The percentages of the remainder were similar $(55 \%-$ mild degree, $57 \%$ - severe degree);

3. The majority of respondents (74\%) approach the participation in sports-recreational activities not only as a form of therapeutic rehabilitation. The data from three regions were similar. Every fourth respondent on average was of an opposite opinion (considered motor activities exclusively as a form of therapeutic rehabilitation);

4. The respondents most frequently participated in walks and marches $(56 \%)$, followed by rehabilitation gymnastics $(51 \%)$. The largest percentage of respondents had never participated in hydrobics $(86 \%)$, horseback riding, hyppotherapy (75\%), and swimming (56\%);

5. The largest number of the disabled in the study would like to participate in walks and marches (59\%), rehabilitation gymnastics (58\%), team games (45\%), and swimming (42\%). They would never like to participate in hydrobics (53\%), horseback riding, hyppotherapy (41\%), and swimming (32\%);

6. According to the respondents' opinions, the forms of sports-recreational activities most recommended with respect to the degree and type of disability were: rehabilitation gymnastics (68\%), walks and marches $(57 \%)$, and swimming (44\%);

7. The disabled mentioned the following benefits from the participation in sports-recreational and tourism activities: good general wellbeing (49\%), improvement of the state of healthy (45\%), making new acquaintances, social contacts and friends (41\%), elevation of efficacy and physical endurance (37\%). Attention was also paid to the change of sedentary style of life (34\%), and satisfaction from overcoming imperfections of own body and anxiety resulting from disability (25\%). 
Postulates

1. The majority of respondents participate in sports-recreational activities; however these are most frequently commonly available forms, such as walks and marches, rehabilitation gymnastics, considerably more rarely team games and swimming. Despite the fact that the respondents considered these forms as most attractive and most recommended for them, it would be advisable to take care of a greater variety and targeted selection of these activities, especially with respect to the degree and type of disability. This would be an opportunity for the disabled to improve their state of health, physical efficacy, and change to-date habits;

2. The respondents who do not wish to participate in sports-recreational activities, especially due to their poor state of health, inability to walk and limited contact, require special interest and care. The reminder who refuse to participate because of the lack of time, strength, low efficacy and low general wellbeing, should most of all be made aware of the health promoting role of physical activity, should be provided assistance with the organization and participation in this type of activities, as well as convinced to first undertake an attempt to participate, and later decide if these activities suit them. A basis for changing their attitudes towards participation in sports-recreational activities is primarily self-confidence (I can), and proper motivation (I want).

\section{Acknowledgement}

The study was conducted within the project financed by the National Fund for Rehabilitation of the Disabled (PFRON) during 2005-2007 entitled: "Social conditionings of participation in tourism and recreation among the disabled from the areas of eastern Poland in tourism and recreational activities" under the direction of Prof. dr. habil. Józef Bergier.

\section{REFERENCES}

Barlak, M., Włostowska, K. (2006). Integracyjne wartości aktywności fizycznej niepełnosprawnych /Integration value of physical activity of the disabled/. In J. Bergier, Z. Kubińska (Eds.), Kultura i rekreacja ruchowa w integracji osób niepetnosprawnych /Motor culture and recreation of the disabled/ (pp. 222 -227). Biała Podlaska: PWSZ w Białej Podlaskiej.

Bekesi, A., Torok, S., Kokonyei, G., Bokretas, I., Szentes, A., Telepoczki, G. (2011). Europan kidscreen group, healthrelated quality of life changes of children and adolescents with chronic disease after participation in therapeutic recreation camping program. Health and Quality Life Outcomes, 9, 43.

Bergier, B., Bergier, J., Kubińska, Z. (2010). Environmental determinants of participation in tourism and recreation of people with varying degrees of disability. Journal of Toxicology and Environmental Health, 73(17-18), 1134-40.

Blauwet, C., Willick, S.E. (2012). The Paralympic Movement: using sports to promote health, disability rights, and social integration for athletes with disabilities. PMR; 4(11), 851-6.

Burns, N., Paterson, K., Watson, N. (2009). An inclusive outdoors? Disabled people's experiences of countrywide leisure services. Leisure Studies, 28(4), 403-17. DOI: 10.1080/02614360903071704.

Buzinde, C.N., Yarnal, C. (2012). Therapeutic landscapes and postcolonial theory: a theoretical approach to medical tourism. Social Science \& Medicine, 74(5), 783-87.

Chockalingam, N., Thomas, N.B., Duval, L. (2012). Should preparation for elite sorting participation be included in the rehabilitation process of war-injured veterans? Prosthetics and Orthotics International, 36(3), 270-7.

Cocchiarella, A.J., Sperling, R.A., Bates, J.F., Schacter, D.L., Rosen, B.R., Albert, M.S. (2001). Encoding novel facename associations: a functional MRI study. Human Brain Mapping, 14(3):129-39.PMID: 11559958

Freeman, I., Selmi, N. (2010). French versus Canadian Tourism: Response to the Disabled. Journal of Travel Research, 49(4), 471-85. DOI:10.1177/0047287509349268.

Konwencja o prawach osób niepełnosprawnych, sporządzona w Nowym Jorku dnia 13 grudnia 2006r. (The Convention on the Rights of Persons with Disabilities adopted on 13 December 2006) Dziennik Ustaw RP, Warszawa, dnia 25 października 2012r. poz.1169.

Kubińska, Z., Bergier, B., Bergier, J. (2011). Uczestnictwo w turystyce i rekreacji ruchowej osób niepełnosprawnych zamieszkałych w miastach i wsiach województwa lubelskiego /Participation in tourism and motor recreation of the disabled living in urban and rual areas of the Lublin Region/. Medycyna Ogólna i Nauki o Zdrowiu, 17(4), 189-193. 
Murphy, N.A., Carbone, P.S. (2008). American Academy of Pediatrics Council on Children With Disabilities: Promoting the participation of children with disabilities in sports, recreation and physical activities. Pediatrics, 121(5), 1057-61.

Murray, M., Sproats, J. (1990). The Disabled Traveller: Tourism and Disability in Australia. Journal of Tourism Studies, 1, 9-14.

Riley, B.B., Rimmer, J.H., Wang, E., Schiller, W.J. (2008). A conceptual Framework for improving the accessibility of fitness and recreation facilities for pe ople with disabilities. Journal of physical activity \& health, 5(1), 158-68.

Robinson, T.C., Kristjanson, L.J., Coleman, M.E.,Maltby, H., Jackson, G. (2004). Psychometric testing and refinemend of the Support Needs Inventory for Parents of Asthmatic Children. Journal of Nursing Measurement ,12(3), 17993.PMID:16138724.

Sikorska, J. (2005) Niepełnosprawność w Polsce - wzrost skali problemu na przestrzeni ćwierćwiecza /Disability in Poland - an increase in the scale of the problem within a quarter of the century/. In Człowiek - Niepetnosprawność Społeczeństwo /Humans-Disability-Society/, 1, APS Warszawa.

Smith, W.R. (1987). Leisure of Disabled Tourist: Barriers to Participation, 14, 376-89.

Solignac, M., (2004). Osteoarthritis, disability, travel and recreational activities: comments from physicians and Travel specialists. Press Med., 22; 33 (9 Pt 2), 19-20.

Spinhoven, P., Ker Tuile, M., Kole-Snidjers, A.M.J.,et.al. (2004). Catastrophising and internal pain control as mediators of outcome in the multidisciplinary treatment of chronic low back pain. European Journal of Pain, 8, 211-19.

Suzukowa, M., Shimada, H., Makizako, H., Watanabe, S., Suzuki, T. (2009). Incidence of falls and fractures in disabled elderly people utilizing long-term care insurance. Nihon Ronen Igakkai Zasshi, 46(4), 334-40.

United Nations General Assembly (2006). Final report of the Ad Hoc Committee on a Comprehensive and International Convention on the Protection and Promotion of the Rights and Dignity of Persons with Disabilities. 2006 Retrieved from http://www.un.org/esa/socdev/enable/rights/ahcfinalrepe.htm

Wilken, U. (1997). Tourism and handicap progress in integration into general travel and vacation services. Rehabilitation (Stuttg), 36(2), 121-5.

Zdebski, J., Gordon, A. (2005). Integracyjna rola krajoznawstwa i turystyki osób niepełnosprawnych w Polskim Towarzystwie Turystyczno-Krajoznawczym /ntergation role of sightseeing among the disabled in the Polish TourismSightseeing Association/. In F. Midura, J. Żbikowski (Eds.), Krajoznawstwo i turystyka osób niepełnosprawnych /Sightseeing and tourism among the disabled/ (pp. 11-14). Biała Podlaska: Wyd. PWSZ im. Papieża Jana Pawła II w Białej Podlaskiej.

AUTHOR'S ADDRESS:

\author{
Barbara Bergier \\ Państwowa Szkoła Wyższa im. Papieża Jana Pawła II \\ 95/97 Sidorska str. \\ 21-500 Biała Podlaska \\ Poland \\ E-mail: barbara.bergier@wp.pl
}

